\title{
TREASURY CONTROL OF ESTABLISHMENTS
}

\begin{abstract}
$\mathrm{A}^{\mathrm{L}}$ LTHOUGH the fifth report from the Estimates Committee for Session 1963-64, dealing with Treasury Control of Establishments, was published in May 1964 (see Nature, 203, 797; 1964), it was not discussed in Parliament until February 23, 1965. A feature of this debate in the House of Commons, however, was the attention directed to those recommendations of the Committee which relate to the recruitment and use of scientists. The debate was opened on a motion of Sir Eric Errington, chairman of the Estimates Committee, asking the House to note this report and the subsequent ninth report of the Committee, containing the replies of the Treasury, pub. lished in July. Sir Eric himself dealt chiefly with other recommendations of the Committee, noting that the Treasury had fully recognized its ultimate responsibility to the House of Commons for the control of complements and grading; this was confirmed by Mr. N. MacDermot, the Financial Secretary to the Treasury, in replying on the debate. Sir Eric enquired as to the strengthening of the Establishments (Complementing) Division, the delegation of authority to Departments, which, in principle, the Estimates Committee approved, and the establishment of work study units. He asked that the Government should reconsider the percentage addition to the depart. mental staffing of the Foreign Service. Although a SubCommittee of the Estimates Committee is examining further the subject of recruitment for the Civil Service, Sir Eric enquired specifically whether there had been any changes in development at the Centre for Administrative Studies, and what decisions had been taken on the report of the Joint Working Party on Training. He also enquired whether any action had been taken on the Estimates Committee's ninth recommendation that the scientific side of the Civil Service be reorganized.
\end{abstract}

Mr. J. Rankin, who followed, after enquiring about the use of computers, also asked if the examination of the Scientific Civil Service, including questions of career structure, had been completed and whether the inadequate recruitment of scientists noted by the Estimates Com. mittee was due to the unsatisfactory prospects for a career. Mr. A. Hopkins, after welcoming the Treasury's acceptance of the Estimates Committee's ninth recommendation that the Treasury should take positive steps to stimulate the recruitment of scientists by producing a better careor structure within the Scientific Class and encourage the transfer of members of the Scientific Class to the Administrative Class, asked what progress had been made. He emphasized the significance of the evidence given to the Committee by Sir Ronald Holroyd as to the virtual non-existence of a dividing line between scientist and administrator at the highest levels in Imperial Chemical Industries, Ltd. He hoped that in the Civil Service the barrier to transfers betweon the Scientific and Administrative Classes no longer existed. He, too, emphasized the importance of adequate use of computers and of establishing some links between the Civil Service and industry, both at home and abroad. This last. mentioned point was also pressed by Mr. W. Hamilton, who referred to the establishment of work study units in Departments employing large numbers of industrial staff, and like all the proceding speakers referred to the need for a better career structure within the Scientific Class. He thought that this was one of the most important recommendations of the Committee and that this question of the status of the seientist and technologist might well be related to the vacant places in science and technology at our universities and colleges of technology. Com- menting on the denial of the suggestion that a scientist in the Civil Service could not become a Departmental Head or Permanent Secretary, he asked how many scientists had reached such positions in the past ten years. He hoped that the present examination of the career structure of the Scientific Class would sweep away any remaining obstacles to transfer from the Scientific to the Administrative Class.

The next speaker, Mr. I. Lloyd, urged the full use of computers, but Dr. J. Bray was concerned mainly with the control of expenditure, in the light of the earlier recommendation of the Plowden Committee that most expenditure could not be effectively controlled by annual estimates alone. He thought it necessary to institute some form of review of commitments as distinct from an annual review of commitments. Since the publication of the Estimates Committee's report there had been a major reorganization of the Treasury, and he believed that the question should be carefully considered whether the establishment of a new Department of Economic Affairs contributed to the efficient discharge of the Treasury's responsibilities for control of establishments or whether its responsibility for personnel should be transferred to an independent and strengthened Civil Service Commission. Mr. W. Clark, who also raised a similar point, pressed the question of computer and of work study, and expressed anxiety about transfers and loss of staff generally. He urged the importance of contact between scientists in the Civil Service and those in industry, and suggestod that there should be more liaison in this field.

In replying on the debate, the Financial Secretary to the Treasury agreed that a sense of responsibility among Departments should be encouraged, and stated that the Treasury had accepted nearly all the Committee's recommendations. The April review of manpower would be abolished subject to the qualification that there were half a dozen manpower ceilings which it was still necessary to fix on a six-monthly basis. Each Department knew precisely at what date it was required to make its returns, and an interdepartmental review of arrangements for delegated authority had been completed and had led to the level of delegation being raised. The Departments themselves were generally well satisfied with the level of delegation, and Treasury control over the higher posts and total numbers remained. The recommendation for a systematic examination by the Establishments (Comple. menting) Division every $3-5$ years had been substantially accepted and progress with the inspection programmes would be reviewed this summer. On the percentage of reserve manpower for Overseas Service, Mr. MacDermot said that although the 10 per cent limit suggested by the Plowden Committee had been rejected, the $7 \cdot 5$ per cent agreed by the Treasury, which would mean in effect a reserve of 450 , was being built up gradually but was not, expected to be reached before the end of 1965 . The recommendation for the establishment of work study units had been implemented, and the Ministry of Public Building and Works was represented on the joint work study committee over which Mr. P. Chambers, chairman of Imperial Chemical Industries, Ltd., presided.

$\mathrm{Mr}$. MacDermot then said that steps for stimulating the recruitment of scientists by producing a better career structure were still being examined. A special committee, on which several Government scientists and at least two from outside were serving, was examining the whole structure and examination of the Scientific Civil Service, and its report was expected in the spring. While the 
Treasury welcomed the proposal for more froquent transfers of scientists to the Administrativo Class, Mr. MacDermot thought that the reluctance of young scientists to take administrative posts was a practical difficulty and Britæin should perhaps sook to encourage those with the necessary aptitude to move into the Administrative Class at a lator rather than an earlier stago in their carcor. Movement in the reverse direction was exceedingly difficult. Encouraging results had been obtained in a trial transfer of thirtcen scientists to the principal grade of the Administrative Class. On exchanges between the Civil Service and industry, he said that more than 100 exchanges in the professional Administrative and Scientific Classes for short periods between the Civil Service and the private sector and nationalized industry had occurred in 1961- 63 . Opportunities for interchange of ideas and experience wero to be found at the Contro for Administrative Studies and in many management and similar courses elsewhere. The Government wishod to increase these opportunities. The question of a Civil Service staff college would bo further examined in relation to the long-term future of the Centre for Administrative Studies, where assistant principals now attended a three-week course on the structure of Government within the first six months of entering the Service. They attended a full 20-week course in their third year of service, doaling with economics, statistics, mathematical and other new techniques of administration. It was hoped that this year twenty members of the principal grade would take a six-week course in economies; an induction course for the professional, scientific and technical classes was being considered. On computers, he said there wore now 41 installed computers, 10 on order and possiblo requirement for 42 by 1970 .

\section{DEVELOPMENT OF INVENTIONS BILL}

$\mathrm{T}$ HE Devolopment of Inventions Bill, which reccived an unopposed second roading in the House of Commons on February 18, amends the Development of Inventions Acts of 1948-54, which establishod the National Research Development Corporation for securing the development and exploitation of inventions where roquirod by tho public interest. Under tho 1948 Act, the Board of Trade was empoworod to advance capital to the Corporation, and all the functions of the Board under these Acts have now been transferred to the Ministry of Technology by the Ministry of Technology Order, 1965. In moving the sccond reading, the Minister of Technology, Mr. F. Cousins, said that the previous Government had already announced on July 28 that it proposed to seek powers to extend the scope and scale of the work of the Corporation so that it would bo able to contribute more effectively to industrial innovation and developmont, particularly development in which industry shared the risk. That was the essential element of the Bill before the Houso, and it also included the proposal of the previous Government to raise the Corporation's present limit of borrowing power to $£ 25$ million. The Government also agreed that legislation should provide for a modification and extension of the financial and other conditions under which the Corporation operated, so that in partnership with industry it would have greater freedom to promote the development and commercial application of new techniques. The present Bill was built on these proposals, but the Government intended to make a slightly wider use of the powers of the National Research Devolopment Corporation. As to the purposes of the Corporation, $\mathrm{Mr}$. Cousing commented that by 1954 it had been realized that research to assist in tho dovelopment or exploitation of an invention was a necessary part of the Corporation's role, but that it had now become clear that further action was required. Essentially tho Corporation's work could be classified under three heads. First, the patenting and licensing to industry of inventions which wore already capable of practical application; secondly, assisting the development of inventions; thirdly, assisting research likely to lead to newer developments. For somo time past the second role had been assuming groater importance, and it was hero that major expansion was anticipated in futurc. So far research had not resulted in as much return as exploitation, or as much oxponditure as development, but had covered some important projects, and it was now clear that a longer period was oxpocted than had been originally envisaged beforo a return could bc obtained on research and dovelopment expenditure. The average period was now estimated to be about eight years. So far the Corporation had received about $£ 2$ million in royalty revenue, and, out of the $£ 6$ million which had been invested in development, about $\AA_{1} .4$ million had been recovered. Mr. Cousins also stressed the importance of co-operation between the Corporation and the Atomic Enorgy Authority, and said that Mr. Duckworth, the managing director of the Corporation, had accepted his invitation to serve on the Authority.

Turning to the Bill itself, Mr. Cousins said that Clauso 1 increased the capital at the disposal of the Corporation from $£ 10$ million to $\$ 25$ million and the time limit on its use had been removed. Certain alterations were also made in the accounting and in reporting the Corporation's activities under this Clause. Under Clause 2, if the Corporation had to write off a development project, wholly or in part, it could ask the Minister for a direction that it would no longer be liable to repay a corresponding sum from advances made to it. This Clauso also provides that any amount so writton off should still count against the $\$ 25$ million limit. Under Clause 3, the Minister could relieve the Corporation of the burden of interest for the first eight years of any advance, corrosponding with the average maturity period of a development project. Clause 4 extended the scope of the Corporation's activities, enabling Government departments, with the exception of the Post Office, which already had power to do so, to ask the Corporation to undertake projects at the expense of their own votes, and to pay the Corporation a management fee for doing so. This Clause provided that the Minister of Technology must approve the arrangement, and gave the Corporation the option of declining to take on projects proposed by Government departments. It was considered that the Minister must retain a general oversight of the Corporation's operations to prevent it from being overloadod, and that the Corporation must have the right to decline to carry out a particular project, bccause there might be incompatibility between such a project and the obligations that the Corporation had already accopted. Clause 6 enables the Minister to increase the mombership of the Corporation from 10 to 12 , and made it clear that the Corporation's duty under the Acts to balance its accounts was not to be taken as preventing it from so exercising its functions as to make a surplus on revenue accounts. In replying on the debate for the Government, the Minister of State for the Board of Trade, Mr. G. Darling, made no comment on the point raised by Mr. Marples concerning the future of the Joint Development Committee set up between the Corporation and tho Department of Scientific and Industrial Research. 